\title{
PEDAGOGIES OF THE POOR: RESISTING RESILIENCE IN EASTERN EUROPE AND BEYOND
}

\begin{abstract}
This article illustrates the different ways in which the poor are being put to work, in defence of a global neoliberal order by global economic institutions concerned with constructing them as resilient subjects, as well as by opponents of neoliberalism concerned with galvanizing the revolutionary potentials of poor people. In spite of the apparent gulf between neoliberalism and its revolutionary opponents, the poor find themselves subject to remarkably similar strategies of construction by both proponents and opponents of neoliberalism today. This predicament of the poor is particularly vexed in Eastern Europe where strategies of resilience are fast developing, and critical legal theory has so far offered little resistance to this trend. Turning against this tide, this article considers how we might reimagine poverty and conceive its politics beyond and against clichéd images of the poor as resilient subjects. Through an analysis of the work of the Hungarian filmmaker Bela Tarr, it argues for the necessity of images capable of conveying the intolerability of the conditions in which the poor continue to live, as well as the contingency of those conditions; images that serve as interventions on narratives which would reduce the poor to a life of mere resilience.
\end{abstract}

Keywords: resilience, poverty, cinema, neoliberalism, commons, Roma, Eastern Europe, Béla Tarr.

\section{INTRODUCTION}

This article illustrates the different ways in which the poor are being put to work, in defence of a global neoliberal order, by global economic institutions concerned with constructing them as resilient subjects of that order, as well as by opponents of neoliberalism, in theories of social and political transformation concerned with galvanizing the revolutionary potentials of poor people. In spite of the apparent gulf between neoliberalism and its revolutionary opponents, the poor find themselves subject to remarkably similar strategies of construction, when we compare the ways in which they are imagined and conceived by both proponents and opponents of neoliberalism. On both left and right we encounter an assumption as to the unbreakability and endless resourcefulness of poor people. Whichever way they turn the poor find themselves vulnerable to this strategy of subjectification, which seeks to convince them of their resilience, and which invests in it, as a source for political and social transformation.

\section{*Professor of International Relations, University of Lapland, julian.reid@ulapland.fi}


It is a fact, of course, that in Europe poverty is much higher in the East than in the West (Menchaca 2018). Rural poverty is particularly high in Eastern Europe, leading to mass migration, especially of the young, westward and into cities. The Roma are said to be especially poor and prone to migrate, and since 1989 have become target subjects for European development programs in the West, which today are aimed at making them 'resilient' (Fisher, Buckner 2018; Morell et al 2018; Van Baar 2018). At the same time resilience as a concept is said to be under-developed in the Eastern European context, 'missing from post-socialist discourses' and lagging in its application to rural communities in Eastern Europe (Lendvay 2016, 255). It is inevitable that the concept and discourse of resilience, and its application to Eastern European poor is going to grow over the coming years, with at best dubious implications for their lives (Chandler, Reid 2016; Evans, Reid 2014; Reid 2013; Reid 2012).

\section{RESILIENCE IN LAW; WHERE IS THE CRITIQUE?}

In legal theory resilience has powerful proponents, as legal scholars argue that 'existing law is too inflexible to accommodate resilience thinking' (Allen et al 2014, 4). Environmental law, in particular is under considerable pressure to import resilience theory and develop frameworks that are seen to be 'adaptive' in their capacities to govern ecosystems that are said to be instable and dynamic, yet also resilient to change and pressure, and capable ultimately of absorbing the shocks of disasters (Arnold, Gunderson 2013). Arguments for the development of resilience in the field of environmental law arise from concerns that existing legal regimes are based on outdated understandings of nature as relatively stable, linear in their development, and predictable in their patterns of change. However the importation of resilience into law is also impacting on social systems, and scholars argue that there is insufficient attention paid to the ways in which this shift in law impacts on society (Cosens 2013). The demands now made on the poor to be resilient reflects the fallacious assumption that ecosystems and social systems follow the same laws and can thus be governed on the same principles. The legal theorist, J.B. Ruhl, has argued precisely this, that poverty is a 'complex adaptive system', and that its governance depends on the same principles as every other complex adaptive system, including the law itself, which also is said by Ruhl to be itself yet another complex adaptive system of which we need to develop the resilience thereof (Ruhl 2012).

In other words, law and legal theory is increasingly a part of what has been named 'the resilience machine' (Bohland, Davoudi, Lawrence 2019). When will critical legal theory wake up to the dangers of this shift? For years now, Costas Douzinas and his collaborators in the project of introducing criticality into legal thought have been arguing for the necessity of examining the functions of law in ideological and imaginary constructions of human subjectivity (Douzinas, Gearey 
2005). Yet the legal critique of the incorporation of law into the resilience machine remains hitherto non-existent. Indeed, even within critical legal theory itself we can find the resilience machine at work. Anna Grear, writing for the influential journal, Law and Critique, itself edited by Douzinas, has argued that critical legal scholarship needs to get busy with delivering resilience in today's world of climate crisis and what, as we will see later, is now called the Anthropocene (Grear 2015, 246). If legal critique is to meet the challenges which it has posed for itself, as expressed clearly by Rafał Mańko, of exposing the function of law in maintaining hegemonic ideology, as well as the function of hegemonic ideology within law itself, then it needs to address, also, the ways in which 'critique' itself too often serves to mask ideology (Mańko 2018). Legal critique is no exception to this danger of 'critique' turning toxic. Central and Eastern European scholars of law need to be made particularly aware of the dangers inherent in resilience ideology, and of getting caught up in the resilience machine, if they are to meaningfully 'resist the present' as has been urged necessary (Mańko, Cercel, Sulikowski 2016. The raising of such awareness is especially pressing given the ways in which the European Union and other agencies of western colonialism now have Eastern and Central Europe in their sights.

\section{REIMAGINING POVERTY}

Attempting to turn against the tide of these trends, this article will consider how we might reimagine poverty and conceive its politics beyond and against clichéd images of the poor as resilient subjects. It addresses in particular the politics that emerges when we ground social relations in a project of both breakability and unfixability - the method guiding Lauren Berlant's pedagogy of poverty; a pedagogy aiming to teach and train the poor to live with what is broken. While opposed to the neoliberal agenda of resilience, Berlant's pedagogy is equally problematic as it functions by dispossessing the poor of belief in any capacity for security, teaching them to accept loss and damage as inevitabilities of living. Ultimately I argue for the necessity of better images of poverty, capable of breaking from the clichéd and degrading representations of the poor to be encountered in much of political discourse today. Images capable not only of conveying the intolerability of the conditions in which the poor continue to live but the contingency of those conditions; images that serve as interventions on narratives which would reduce the poor to a life of endless struggle, resilience and suffering. For the purpose of locating new and non-cliched images of the poor and their potentials I will turn to the resources of cinema, and especially the cinematic imaginary of the Hungarian Bela Tarr, whose work has been identified as existing in the vanguard of Eastern European cinema (Kiraly 2015), and whose last film, The Turin Horse addresses these phenomena of rural poverty, migration and Roma subjectivity directly. 


\section{THE UNBREAKABLE POOR}

So-called natural disasters, such as earthquakes and floods, pose particular threats to the security and wellbeing of Eastern European states and their peoples. Romania, for example, faces some of the greatest seismic risks of any European state, which is one reason why the World Bank, this summer of 2018, lent the country 400 million Euros to develop its disaster risk management policies (Banila 2018). 'Increasing resilience to shocks is a central element of our new strategy for Romania, as well as the core of our efforts to promote inclusive growth', has said the World Bank country director for Romania and Hungary, Tatiana Proskuryakova (Banila 2018).

Early in 2017, the World Bank published a more general report on the implications of natural disasters for the poor worldwide. As the report describes natural disasters have a tendency to impact on the poor much more than they do other populations of a society. Moreover they hurt the poor in ways that cannot be measured according to the traditional focus on the impacts of natural disasters on the aggregate wealth of countries.

A flood or earthquake can be disastrous for poor people, but have a negligible impact on a country's aggregate wealth or production if it affects people who own almost nothing and have very low incomes. By focusing on aggregate losses, the traditional approach examines how disasters affect people wealthy enough to have wealth to lose and so does not take into account most poor people (Hallegatte et al 2017, 1).

The report laments this traditional shortcoming in the measurement of disaster impacts, and argues for the greater worth of its own approach which, eschewing the measurement of aggregate losses, focuses instead 'on how disasters affect people's well-being' (Hallegatte et al 2017, 2). The metric it adopts aims to measure the overall affects of disasters on both poor and non-poor populations such that the management of disasters can work to the benefit of the poor as much as the non-poor, taking into consideration, as it aims to, the greater vulnerabilities of the poor, and indeed, their well-being.

The report is titled Unbreakable: Building the Resilience of the Poor in the Face of Natural Disasters. The title tells a lot about the overall disposition of the report, and we might suppose that of the World Bank as a whole, towards poor people as such. On the one hand an articulated concern for the well-being of the poor in the context of a world in which natural disasters are endemic and worsening in their effects, and on the other, a profound faith in the abilities of the poor to withstand those endemic effects. Unbreakable. Resilient.

This ascription of unbreakability and resilience to the poor in the face of their exposure to the death and damage wrought by disasters worldwide has become a governing cliché in recent years in policies and literatures concerning disasters 
and poverty (Chandler, Reid 2016; Reid 2013; Evans, Reid 2013; Reid 2012). It is a cliché which the World Bank has been particularly powerful in pushing, along with other international organizations, concerned as they are with formulating policy solutions to poverty which will not interfere with the smooth running of capitalism (Felli 2016). Unbreakability is of course one thing, while resilience is another. To be resilient is not simply to be unbreakable, but to be able to absorb the shock generated by the impact of a disaster, and recover by adapting to its occurrence, not by returning to the state one was in prior to the disaster, but by evolving in form, learning from the event of disaster, and growing stronger from the knowledge established of one's vulnerability. Affirming the resilience of the poor is therefore also to affirm the productivity of disasters for their life and wellbeing, and not simply to lament their excessive exposure to disasters. It is a way of not only naturalizing that exposure, but celebrating it, as that without which the poor would not be able to lay claim to their core property of resilience. The unbreakability of the poor is predicated on their resilience, which in turn requires their exposure to disasters in order for it to develop.

The identification of resilience as a core property of poor people has a relatively recent history. Prior to that resilience was largely conceived as a property of non-human living systems within life sciences, especially ecology. Its reconceptualization as a property of human life, and its identification with poor people especially, can be traced to the 2002 World Summit on Sustainable Development in Johannesburg. A major report prepared on behalf of the Environmental Advisory Council to the Swedish Government as input to the process of the Summit introduced the concept of resilience to the human development community, describing how resilience is a property associated not just with the diversity 'of species', but also 'of human opportunity', and especially 'of economic options - that maintain and encourage both adaptation and learning' among human populations (Folke et al 2002, 438). Neoliberal economy, in which the function of markets as generators of economic diversity is basic, was recognized as a core constituent of the resilience which sustainable development had to be aimed at increasing. Thus was it that, postJohannesburg, the correlation of sustainable development with resilience started to produce explicitly neoliberal prescriptions for institutional reform. 'Ecological ignorance' began to be conceptualised as a threat, not just to the resilience of the biosphere, but to humanity (Folke 2002, 438). Resilience began to be conceived not simply as an inherent property of the biosphere, in need of protection from the economic development of humanity, but a property within human populations that now needed promoting through the increase of their 'economic options.' As remarkably, the biosphere itself began to be conceived not as an extra-economic domain, distinct from and vulnerable to the economic practices of human populations, but an economy of 'services' which 'humanity receives' (Folke et al 2002, 437). 
There was a double and correlated shift at work, here, then, in the elaboration of the sustainable-development-resilience nexus post-Johannesburg. In one move 'resilience' shifted from being a property of the biosphere to being a property of humanity, while in a second move 'service' shifted from being an element of economy to being a capacity of the biosphere. Crucified on the cross that this double shift carves were the poor. For they were the population within humanity of which resilience was suddenly most demanded and simultaneously the population said to threaten the degradation of 'ecosystem services.' Increasing the 'resiliency' of the poor has become a defining goal, for example, of the United Nations Environment Programme (UNEP) in the years post-Johannesburg (UNEP 2004, 39). Alleviating threats to the biosphere requires improving the resilience of the poor, especially, because it is precisely the poor that are most 'ecologically ignorant' and thus most prone to using 'ecosystem services' in non-sustainable ways. Thus does ensuring the sustainability of the biosphere require making the poor into more resilient kinds of subjects, and making the poor into more resilient subjects requires relieving them of their ecological ignorance, and the means to that removal was argued to reside in building neoliberal frameworks of economy, governance, and subjectivity.

Developing the resilience of the poor was said to require, for example, a social context of 'flexible and open institutions and multi-level governance systems' (Folke et al 2002, 439). 'The absence of markets and price signals' in ecological services is a major threat to resilience, UNEP argued, because it means that 'changes in their conditions have gone unnoticed' (UNEP 2004, 13). Property rights regimes had to be extended so that they incorporate ecosystem services and so that markets can function in them (UNEP 2004, 15). 'Markets' it is argued 'have proven to be among the most resilient institutions, being able to recover quickly and to function in the absence of government' (Pingali et al 2005, 518). When and where the market fails to recover, development policies for increasing resilience had to be aimed at 'ensuring access to markets' (Pingali et al 2005, 518). Ensuring the resilience of the poor also required the building of neoliberal systems of governance that would monitor their use of ecological services to ensure they are sustainably managed (UNEP 2004, 39). The poor, in order to be the agents of their own change, had to be subjectified so that they would be 'able to make sustainable management decisions that respect natural resources and enable the achievement of a sustainable income stream' (UNEP 2004, 5). 'Over-harvesting, over-use, misuse or excessive conversion of ecosystems into human or artificial systems damages the regulation service which in turn reduces the flow of the provisioning service provided by ecosystems' (UNEP 2004, 20). Within 'the poor' itself women were the principal target population. 'I will transform my lifestyle in the way I farm and think' became the mantra that poor women farmers in the Caribbean region were demanded, for example, to repeat like Orwellian farm animals in order to receive European Union funding (Tandon 2007, 12-14). 
Since Johannesburg, resilience has developed into a governing dogma, accepted and proselytized by an ever widening range of actors, more or less univocal in their assertion of the poor's abilities to absorb the shocks of disasters, recover, and grow stronger through their exposure to disaster-ridden worlds. The World Bank's affirmation of this dogma, Unbreakable, is only the latest and doubtless not the last reiteration of this condescending approach to poverty. But there is a particularly dark irony to the way in which the World Bank is now formulating its approach and thinking concerning resilience. For its interest is purely and simply in what it described as 'socio-economic resilience', which is to say, 'the ability of a population to cope with asset losses' (Hallegatte et al 2017, 97). In other words while professing commitment to the wellbeing of the poor and not simply their economic welfare, it is concerned with measuring the risks posed at that wellbeing in fundamentally economized terms. As they readily admit, this represents 'an imperfect metric' for 'it disregards direct human and welfare effects such as death, injuries, and psychological impacts; cultural and heritage losses such as the destruction of historical assets; and social and political destabilization and environmental degradation.' (Hallegatte et al 2017, 100). It also disregards, as they too recognize, 'the impacts of natural disasters on natural capital, in spite of their importance to the income of poor populations across the world through their effects on soils, fish stocks, and trees, among other things (Hallegatte et al 2017, 100). Likewise it deliberately disregards 'the impact of differentiated disaster impacts across people, especially for children, the elderly, and, in some cases, women. Introducing gender inequality and the higher vulnerability of some groups would affect our measure of resilience and well-being losses', the World Bank concedes, citing 'data limitations' (Hallegatte et al 2017, 100). Death, the loss of life, physical suffering and damage, psychological trauma and hurt, the loss of culture, heritage and history, the social and political turmoil, and the impact of disasters on the environments of the poor, including the soils, livestocks, fish, and trees on which they depend, all fall out of the purview of the World Bank, as well as the vastly unequal ways in which risks are shared across genders and age groups, in order to maintain the integrity of its datafied approach to mapping and modeling the 'unbreakable' Poor. The anaemic nature of the conception of wellbeing at work in the World Bank's approach to resilience is of course precisely what enables it to assert the 'unbreakability' of the Poor. Were they to take into consideration the death, loss and suffering caused by disasters, which cannot be quantified, the image of the poor depicted would dilapidate into that of shattered life.

\section{RESILIENT REVOLUTIONARIES}

The question of the nature of the image of the poor, how we see and think about poverty, is also at stake in a text apparently opposed to the policies of the World Bank; that of Michael Hardt and Antonio Negri's work, Commonwealth 
(2009). They too are concerned with challenging what they perceive to be a dominant image of poverty, not simply in economic policies, but deep within political theory and philosophy; that of poverty understood and constructed in terms of misery, deprivation and lack (Hardt, Negri 2009, 39). For them the poverty of a population does not name any such misery or lack but a productivity and resourcefulness that make the poor a constant menace for property owning populations. The poor, they argue, is always inventing 'strategies for survival, finding shelter and producing forms of social life, constantly discovering and creating resources of the common through expansive circuits of encounter' such that 'even in conditions of extreme adversity' the poor remain defined by their productivity (Hardt, Negri 2009, 254). The capacity for the production of 'the common' is, they argue, what distinguishes the poor from property owning populations whose subjectivities are grounded in the enclosure and exploitation of the common (Hardt, Negri 2009, 39-40).

Reading Hardt and Negri on poverty we can observe a comparable strategy of construction to that of the World Bank. The poor are not defined by their weakness or lack but by what may well be called their resilience; the ability to invent new strategies for survival, find shelter, and produce new forms of social life, overcoming whatever adversity they are faced with, while proving their endless resourcefulness. Yet for Hardt and Negri these capacities of the poor are the source of their revolutionary potential rather than their subjection to neoliberal governance. They do not recognize the ways in which their account of the poor, in terms of its resilience, is complicit with a parallel shift in thinking concerning poverty in governing institutions. Yet, as we saw in the previous section, capital is every bit as invested in an understanding of the poor as resilient and unbreakable as its would-be opponents. Nor do they recognize the western bias which shapes their concept of the common; a bias which makes them oblivious to the difficulties to be had in applying it to spatial contexts outside of the west, and to Eastern Europe in particular. This ignorance of the specificities and differences of Eastern to Western European experience runs pretty much throughout their work (Smith, Timar 2010: 115-116).

It is not simply the poor that Hardt and Negri construct as resilient, but that which the poor supposedly produces: the common. The common, they suppose, is resilient to all attempts by state and capital to enclose and exploit it, forever escaping and defying those attempts to render it into property, either in the name of the private or the public. Indeed their interest in the poor is really an interest in this, its purported product, 'the common'. The common as Hardt and Negri theorize it has, from the outset, at least a double meaning. It describes 'the common wealth of the material world - the air, the water, the fruits of the soil' which it is claimed belongs to humanity as a whole (Hardt, Negri 2009, viii) and which is now in crisis on account of the historical exploitation and pollution that human beings have wrought upon it. But it also refers to the results of social 
production that are necessary for social interaction and further production (Hardt, Negri 2009, viii) such as knowledges, languages, images, affects, and so on.

The differences between these two forms of the common (material versus immaterial, finite versus infinite, ecological versus social) are obviously vast. And the relation of the poor to each of them is vastly different too. The poor does not and cannot produce air and water in the ways that Hardt and Negri believe it is capable of producing images and affects. The crisis of the material common is clearly much starker than that of the immaterial in this respect. If the common is resilient to strategies aimed at its enclosure and exploitation then it is in its immaterial and not in its material dimensions. One cannot privatize and destroy the common basis of language and love in the same ways one can privatize and destroy common access to clean air and water.

For Hardt and Negri, however, the doubled aspects of the meaning of the common are not a problem. Indeed the resilience of the common when addressed as the results of social production is identified as the answer to the problem of the vulnerability of the common when addressed as the decreasing natural resources on which the poor also relies. Likewise the relative decline of the state, and the transformations in the function of sovereignty we associate with the neoliberal globalization that followed the end of the Cold War, are seen not so much as problems for the defense of the common, but necessary enablers of socio-political processes for the common to constitute itself as a political subject worldwide; both as that collective subject which is defined by the practices of social production of the common, in terms of its abilities to produce new knowledges, languages, images and affects, as well as that which is defined by its defense of the common wealth of the material world. This is the third sense in which Hardt and Negri theorize the common; as the form of political subject that the poor can become, once it passes through the necessary stages of its development. Neoliberalism, they ask us to believe, is itself productive of the socio-political development necessary for the poor to become the Common.

The emergence of the Common, this new form of political subject, represents the beginnings of a new pastoralism for the poor in world politics; whereby the abilities of the poor to care for themselves become inextricably intertwined with their abilities to care for the earth as much as each other. The promise is that through the constitution of the Common as political subject so the answers to the problems of how to secure the common, ecologically and socially, will be miraculously found too. The concept of the Common is profound, therefore, not so much as a tenable answer to the problems of poverty as well as ecological and social crisis we associate with neoliberalism, but as a mythic expression of the classically liberal desire of political thinkers and activists for a solution to the problem of psychic, ecological and social antagonism; their desire for a world beyond antagonism. Its significance is that of the expression of a classically liberal imaginary, and still existent desire, on the liberal left, for utopia. The Common 
lures with its offer of the possibility of a world beyond the division between public and private - a world beyond that which neoliberalism is still in process of creating (defined by privacy), and beyond that which socialism created historically (defined by the public). A world created by an all-powerful subject, and which through the miraculous deployment of its powers destroys the market (which constitutes the private) and the state (which while once protecting the public now serves the function of protecting the market), while taking care of the environment so damaged historically by state and market.

As a world created by this subject, the Common discloses a particular kind of space, expressive of the particular characteristics of the Common as subject. It is a space that is said to belong to the Common in precisely those ways private and public spaces cannot. This is a particular mode of belonging that lures because it promises to take us beyond the modes of belonging defined by public and private; a mode in which we belong to the space in question without treating it or each other as property. Such a space is one which must be lived and experienced in order to be known - hence the importance of new spaces for constitution of the commons, and the significance in particular of the occupation of formerly public spaces, threatened by privatization, by the Common, such as the squares of major cities, where the Common can be seen to be rising up and constituting itself, since around 2011. Hence the importance, also, of the indigenous poor, and their knowledge and practices, for the constitution of the Common, as indigenous poor are said to possess culturally superior ways of producing common spaces (Trawick 2003). These are spaces in and of which their ideological proponents declare the birth of 'utopia' (Hui 2017, 7); spaces in which 'each person is valued as an organic part of the community and for what he or she can contribute' (Hui 2017, 7); mythical spaces in which the 'powerless subjects of neoliberal regimes' (Hui 2017, 9) transform themselves into the imagined community of the Common. And yet this transformation, of the powerless and poor, is itself mediated by an image of the poor, in its unbreakable resilience, as clichéd as that which the World Bank propagates in its policies for the poor's further subjection to neoliberal economic reason.

\section{LEARNING TO LIVE WITH WHAT IS BROKEN}

Lauren Berlant offers what is in many ways a persuasive critique of the mythic qualities of the Common (Berlant 2016). Indeed she urges us to reject the 'frictionlessness' (Berlant 2016, 396) of this impossible, romanticized and clichéd subject and embrace the realities of ambivalence and frustration instead. Rather than investing in the possibility of being able to transcend the antagonisms of the present, in creation of an absolutely other world, what we need, she argues, is a pedagogy of learning to live with what is broken (Berlant 2016, 394-396). Mythical accounts of the Common, Berlant argues, express the yearning to fix 
what we know, what we see, and what we experience, as being broken, in desire for a liveable life. But while Hardt and Negri may understand it as a means by which to achieve a structural transformation of the broken societies we inhabit, by creating spaces that take us beyond and outside of neoliberalism, Berlant attempts to think the Common as a form that inhabits brokenness itself (Berlant 2016, 393). In this sense her approach to the Common is an extension of her long-existing commitment to understanding the tactics that make life bearable for subjects, even when those tactics offer no solutions to the conditions of their servitude, and even involve attachments which do those subjects further damage; what she calls 'cruel optimism' (Berlant 2011).

What would it mean for the poor to inhabit brokenness, and what is entailed in learning to live with what is broken? For Berlant, answering these questions requires us to conceive the Common as infrastructure (Berlant 2016, 396). Infrastructure is revealed, only, when a body breaks down, because a body that works is oblivious to the infrastructure sustaining it. The greater the health of the body the more the oblivion. In its breakdown, the infrastructure of the body makes itself known, revealing itself, to the eye and/or other senses. Infrastructure is, as Berlant expresses it, 'the living mediation of what organizes life: the lifeworld of structure' $(2016,393)$. When it fails, the structure of which it is the lifeworld, necessarily suffers too. However the failure of infrastructure is also a constitutive part, Berlant argues, of the creative process through which living systems, including human societies, develop and sustain themselves over time $(2016,403)$. In their recovery from failure, Berlant argues, infrastructures do not simply fix the problems that caused their failures, but instead indicate the emergence of new forms of life. The austerity policies issued by neoliberal governments in response to the economic crises of recent years are attempts to fix what is no longer working (capitalism). The anti-austerity movements such as Occupy, in the United States, and other related movements throughout both Western and Eastern Europe and elsewhere (Kaun, Murru 2018), are attempts to innovate at the level of infrastructure (Berlant 2016, 394). 'The question of politics', she argues, has today become 'identical with the reinvention of infrastructures for managing the unevenness, ambivalence, violence, and ordinary contingency of contemporary existence' (Berlant 2016, 394). It is in this context that Berlant urges us to recover by what she calls 'unlearning the expectation of sovereignty as self-possession' (Berlant 2016, 408). It is in this sense that the struggle over and for the Common is most important - as attempts to constitute new forms of infrastructure for social living in which the practices of the self, including its economies of possession, are to be reinvented.

The Common is, for these reasons, also to be conceived, less as a world, and more as a place, to which the poor might go, in order to be dispossessed, of their possessiveness; a place where they are possessed rather than practice possessiveness; a place where they can be dissolved of their attachments 
to sovereignty and instrumentality; a place of non-use. Berlant's practice of becoming common offers in that sense a positive version of what Judith Butler and Athena Athanasiou have theorized as dispossession (Berlant 2016, 402; Butler, Athanasiou 2013). A place, then, where people are not secure, and where they go, to an extent, to experience insecurity. Indeed we must welcome the exposure to hurt and potential suffering which the place of the Common offers to us and our fellow poor, and engage in a new form of 'training', she urges, which 'collapses getting hurt with making a life' (Berlant 2016, 411).

In search of an image with which to depict this space she desires the Common to be, Berlant reaches for the circus (Berlant 2016, 411). The image of the circus foregrounds, for Berlant, the difficulty of maintaining footing and balance, and the exposure to the possibility of getting hurt, in the process of 'relearning a capacity for the common' (Berlant 2016, 411). To furnish this image Berlant turns to cinema, and the documentary film of Liza Johnson, In the Air (2009). The film was shot in the city of Portsmouth, in the state of Ohio, in the United States; a city abandoned by capital, leaving one industrial employer, a scrapyard (Berlant 2016, 409). It is a film that depicts a ghost town, in classic terms, of empty streets and buildings, as if captured in a state of waiting for something or somebody to move in and make use of once again (Berlant 2016, 409). And yet, as Johnson's film reveals, and as Berlant describes, the ghost town is occupied, being home to a population of children, who receive the kind of 'training' within it, of which Berlant dreams, in the neighbourhood Cirque d'Art; a circus school to which they go, in order to escape their derelict parents, and where they learn 'to spin and fall' and 'lean on each other' (Berlant 2016, 411). The circus in question, this circus of Portsmouth, Ohio, as depicted by Liza Johnson in film, is where people can and do go, in order 'to relearn a capacity for the common again' (Berlant 2016, 411). Such learning entails a fundamental redrawing of the boundaries of community, Berlant argues. For the training they receive there 'changes what threatens and what comforts, it changes the referent of dread and the refuge' (Berlant 2016, 411). Life itself, even, is reinvented, for these kids, the 'current crop of dreamers' living in Portsmouth, Ohio (Berlant 2016, 411).

This, then, is a very different image and pedagogy of the poor to those offered either by the World Bank or Hardt and Negri. The poor, Berlant argues, are eminently breakable. The Common represents not that form of subject which the poor might become in expression of their unbreakability, nor is it itself an unbreakable form of subject. Instead it is a radically broken kind of non-subject, and one to which the pedagogue must attend to by teaching it how to live with all that which is broken. The word 'training' appears on multiple occasions in Berlant's text. It is clear from the text that she is very keen on training and that the common is as a place and not a subject also a space where training must occur. Of course training nearly always presumes a trainer, and therefore, a sovereign subject of a kind. Berlant describes the trainer; "we see the teacher in the front of 
the room, and she is getting the kids in sync, to do tricks' (Berlant 2016, 411). No comment let alone judgement is made concerning the otherwise obscured functions of discipline, control and subjection which this training to become common must entail. Yet in the synchronicity demanded for a group circus performance Berlant identifies in the very utopian terms she derides in the images of others, a coming and working together which is the signature of becoming-common. In the abandoned architecture of neoliberal capital the kids of In the Air, in all their white working class bodily diversities and differences, form a synchronous union, and 'the space that someone else probably owns becomes the commons made by movement' (Berlant 2016, 412). Broken, they learn nevertheless to move again. Hurt, they learn nevertheless to feel again. And if they lack the moral, spiritual and political resources with which to fight their abandonment by capital and subjection to neoliberal austerity, they can nevertheless find the belief 'to bear each other' down at the circus school, or at least in Liza Johnson's video (Berlant 2016, 413).

\section{REIMAGINING POVERTY}

Against this debased vision of learning and training, it is imperative we search for and produce new images of poverty and the poor. Political discourse is, like other regimes of production, littered by clichéd images of the poor. Phillip Roberts addresses this reality in his account of the politics of cinematic representations of poverty (Roberts 2017). What interests Roberts is the capacity of cinema to produce images that break from cliché, to reveal the intolerability of poverty $(2017,84)$. Cinema's history is defined by works which revealed the intolerable, and which in the process, challenged the narrative strategies of other works that functioned to legitimize poverty. Gilles Deleuze, from who Roberts takes inspiration, argued that this is precisely what defined the breach between classical and modern cinema. The films for example, of Rossellini, made in the wake of the Second World War, did not just show the viewer images of the poverty of post-war Italy, but characters for whom that poverty was intolerable, and whose lives broke down, on account of that intolerability. Indeed Deleuze went further to argue that at stake in cinema of the post-war era was a new regime of the image $(1989,248)$ constitutive of a 'new race of characters' $(1989, x i)$ defined by its capability to see the intolerable; a cinema 'of the seer and no longer of the agent' (Deleuze 1989,2). This was a cinema that refused to offer the poor any hope that their lives will improve, nor any assurance of their resilience, but instead bore witness, simply, to the intolerability of their conditions. It was not a cinema that promised economic improvement, nor revolutionary transformation. It rejected both such narrative possibilities, to instead face the hopelessness of the lifeworlds of the poor, revealing it, dwelling in the otherwise imperceptible dimensions of their misery, moving beyond cliché, into images that are real, not mythic. 
For Roberts a contemporary example of a cinema exemplifying these characteristics is that of the Hungarian Bela Tarr, whose work has won much acclaim in recent years $(2017,80-92)$. The fact of Tarr being Hungarian is of no relevance it would seem to the analysis of Robert, nor of much significance to the considerably larger and wider literature emanating from the West, which has championed his cinema. If we want to get an account of Tarr's work that situates it within its national or regional genres, or in relationship to the particular concerns of Hungary and its region, then we have to engage with literatures which themselves emanate from the region or are concerned with the region (see Kiraly 2015).

Roberts focuses among other works on Tarr's The Turin Horse (2011). This is a film centred entirely on the lives of an impoverished father and daughter living in an isolated farmhouse where they perform, day by day, the same repetitive tasks of cleaning, cooking, drawing water from the well etcetera, while the world outside of the house portends apocalyptic doom. As Roberts asserts it does not merely show a clichéd image of poverty but reveals the minutiae of the life of the poor $(2017,88)$, involving the viewer in it, in ways that are themselves insufferable. It is not enjoyable to watch, but painful, in its tiresomeness. That the viewer has to work to get through the movie is perhaps part of what Elena Gorfinkel has described as its 'aesthetic of bodily attrition and perseverance, continuity in the face of insoluble, excruciating effort' $(2012,313)$. As Roberts expresses it 'the troubling thing about The Turin Horse is that its poverty seems absolutely normal' $(2017,88)$.

But it is questionable whether The Turin Horse is best understood as a depiction of the life of the poor at all. For it is a film about a horse, as the title suggests. Franklin Ginn addresses this fact in arguing that the film deploys the horse as part of a pedagogy aimed at teaching a lesson as to the need for humans to recognize the depth of their debts and dependencies on non-human forces, in context of the damages done by the human to other species amid the anthropocene (Ginn 2015). In this sense it might be thought of as an example of what is today called 'ecocinema', a new form of cinema the politics of which is defined by its being capable of inspiring progressive eco-political discourse and action among viewers' (Rust, Monani 2013, 3). But this would be to neglect the fact that the horse depicted, the Turin Horse, is not just any horse, but the very horse Nietzsche embraced in the city of Turin, on the morning before his turning mad. As the narrator points out at the beginning of the film, we know much about Nietzsche's gesture; his embrace and tears, in recognition of the condition of the horse, who was being whipped by its owner, but virtually nothing of the horse which was the object of his sympathy. The film itself opens with a long sequence depicting the horse, as it pulls its owner in his cart back to the isolated house in the country where he lives with his daughter, and where the horse is then stationed in the barn. The following day, the owner once more decides to ride to town with the horse pulling his cart. But the horse refuses. Not only does the horse refuse to pull the cart, it also refuses 
to eat. The film depicts the empathetic relation of the daughter to the horse, and the contrast between it and the relation of the father to the horse that emits brutality. The daughter remonstrates with the father, as the horse refuses to move for him, saving it from further brutality. Not only do we see the daughter asking the horse why it is unhappy and why it does not want to eat, but we also see the daughter failing to eat, in construction of a shared refusal of food. Only the father of the house eats heartily. The horse gives expression to what the daughter feels.

It is not the case, in other words, that the significance of the horse's refusal is that it 'prevents the man from going to market' (Roberts 2017, 90). The gesture of the horse's refusal is significant for its rejection of the order to which it is subject by the human, and the man of the house in particular. It concerns the horse and its gestural capacity for refusal, rather than being simply another impediment in the life of poor people. Not only is the horse missing from Roberts' understanding of the object of The Turin Horse, but the two most significant scenes of the entire film also go untreated. For Roberts The Turin Horse expresses the limitations of possibility suffered by the poor; the reduction 'of the possibilities of life to a limited set of predictable opportunities' by a regime of control which operates precisely through the limitation of possibility $(2017,91)$. Poverty, here, according to Roberts, is understood in terms of 'life chances' $(2017,91)$, and control functions through an increasing restriction of these chances, by disconnecting the relations of the poor to the outside. Certainly one can see this expressed in The Turin Horse, in its depiction of the suffocating internality of the house in which the father and daughter live, the difficulty verging on impossibility of their being able to reach the town (given the refusal of the horse to pull the cart) or reach another dwelling (they try and fail). Indeed, in these respects, it can be compared with another film of the present, I, Daniel Blake, made also to great acclaim by Ken Loach, which likewise depicts the operation of control, this time upon the urban poor, and also upon a father-daughter coupling (though they are not biologically related), in the context of neoliberal Britain (2016). In I, Daniel Blake, the disconnection of the poor from the outside, the curtailing of their life chances, by a regime of control is more or less totalizing; there would appear to be no way out, in spite of the desire and attempts to exercise agency of the couple. In The Turin Horse, by way of contrast, the extent and severity of the disconnection is openly contestable.

The latter film is staggered by two tremendous scenes, each of which operates as a kind of intervention on the life of the father-daughter couple. In the first a neighbour arrives at the house asking for brandy. Inside, sitting at a table, and in a long, direct and dramatic monologue, he addresses the patriarch, and denounces the prevailing socio-political conditions of the world outside. In the second, the girl sights a band of horse riders approaching, on the horizon, as she gazes from the window upon the outside. 'Who is that approaching?' asks the father fearfully and quizzically. His daughter indicates that they are gypsies and asks him what they should do. 'Go outside and get rid of them' her father instructs. She 
goes outside, and the camera bears witness to both her and the father's failures to prevent them from robbing their water from their well. What is the point of this scene? Is it to further dramatize the poverty of the couple, and their vulnerability to parasitic forces of control and exploitation? Are the gypsies deployed by Tarr, as has been suggested by Edward Lawrenson, as 'harbingers of disaster' in a manner 'provocatively close to ethnic stereotype' (Lawrenson 2011)?

Such interpretations are to miss the point of the most poignant and important scene of the film. The gypsies are forces of intervention, invading the suffocating insular space of the house and its farmland from the outside. Throughout the film we witness how the couple gaze meditatively upon the outside, literally, from the window of the house, waiting, watching. Indeed the film itself, in its privileging of the space of the window, and its dramatization of the stasis of the occupiers of the house, recalls Hitchcock's Rear Window (1954), but from a peasant perspective. When the outside breaks through, however, and the gypsies appear, they are interpreted as a source of threat. On the part of the couple, and especially the girl, this can as easily be read as a tragic misinterpretation of the potentials for liberation that the gypsies in their counter-example of how a life can be lived pose. They denounce the father directly. 'You're a worm', they tell him; 'you're weak', they say. And, in fact, contrary to the fears of the father, they do not rob the couple of their water, but willingly give money for it, before leaving. Most tellingly, they also speak directly to the girl, asking her, 'why don't you come with us?' Their horses, also, contrast powerfully with the horse of the couple, being well cared for, responsive, and riding fast into the wilderness in harmony with their humans on board. 'The water is ours! The earth is ours!' the gypsies proclaim as they depart, in a tone magisterial in its declaration of their self-acclaimed sovereignty.

There is a further poignancy to Tarr's depiction of gypsies in The Turin Horse that has been utterly missed in the western literatures dealing with the film. The Roma are widely recognized as the poorest population of people of the whole of Eastern Europe. The United Nations Development Programme (UNDP) reports that 'Roma are more likely to live in poverty, have a higher risk of unemployment, stay in school for fewer years, live without access to drinking water, sanitation and electricity, and live in substandard, overcrowded homes. Roma are more likely to suffer from chronic illness and have less access to health services' (UNDP 2018). At the same time, in recent years, and unsurprisingly, they have become particular target populations for programmes aimed at increasing resilience in the region (Fisher, Buckner 2018; Morell et al 2018; Van Baar 2018). In contrast with the governing image of Roma in western discourse today, as vulnerable and abject, Tarr depicts them in an uncanny majesty, far from the frame of resilience which the west seeks to situate them within.

For these reasons it is impossible to agree with Roberts that The Turin Horse depicts a situation of hopelessness and total eradication of the outside (Roberts 2017: 91). And, for the same reasons, is also impossible to agree with Jacques 
Rancière, who has offered a similar reading of The Turin Horse, as well as Tarr's wider oeuvre, as a cinema of such hopelessness and failure (Rancière 2011). It is quite the opposite. What it depicts is the blindness of the poor to the reality of the outside, its openness, and its potential. The father, especially, is a character study in not just blindness but stupidity. A stupidity which functions as a regime of control preventing the daughter from ever realizing her life chances. And a stupidity that explains and justifies the poetic gesture of refusal of the horse of Turin; the very horse, we must remember that Nietzsche embraced, not simply out of sympathy, but in solidarity with its subjection to such a regime.

\section{CONCLUSION}

Deleuze argued that the cinema of post-1945 Italy created an entirely new image of poverty, and showed the viewer the intolerability of that image (Deleuze 1989). Following the end of the Cold War, it has been the work of Tarr, and Eastern European cinema as a whole (Kiraly 2015), to produce another such image, and also to insist on not just that intolerability which Rossellini and others showed, but the powers of the poor to triumph over conditions which would seem otherwise impossibly bleak. The image of the poor in The Turin Horse is not one of unbreakability or resilience. Gradually the couple are broken, the film ending with a scene in which the light sustaining their life finally fades. Nor are they intrinsically intelligent in the manner which Hardt and Negri credit the poor with being. One of them is cripplingly stupid. No regime of learning or training can save them. Penetrating this image of the poor requires doing also what the World Bank refuses to do; breaking down the gender and age inequalities through which the poor are constituted. It also requires looking at this image as that of a more than human poor. For the horse is the most significant subject within the group. Nevertheless it is an image of the poor which itself contains its own outside, and in that outside its own potential to be otherwise. A potential for a poverty which takes what is wants, asserts what it possesses, and celebrates what it is capable of doing, in representation of the reality that life can be transformed into what it is not, and new conditions of being established. This is the lesson, requiring neither training nor learning, which the pedagogy of The Turin Horse gives its viewer.

\section{BIBLIOGRAPHY}

Allen, Craig R. David G. Angeler. Ahjond S. Garmestani. Lance H. Gunderson. C. S. Holling. 2014. "Panarchy: Theory and Application". Ecosystems 17(4): 578-589.

Baar van, Huub. 2018. "Contained Mobility and the Racialization of Poverty in Europe: the Roma at the Development-security Nexus". Social Identities: Journal for the Study of Race, Nation and Culture 24(4): 442-458. 
Banila, Nicoleta. 2018. "World Bank lending Romania 400 mln euro for disaster risk management". SeeNews: Business Intelligence for South East Europe. https://seenews.com/news/worldbank-lending-romania-400-mln-euro-for-disaster-risk-management-617880

Berlant, Lauren. 2011. Cruel Optimism. Durham: Duke University Press.

Berlant, Lauren. 2016. "The Commons as Infrastructure for Troubling Times". Environment and Planning D: Society and Space 34(3): 393-419.

Bohland, Jim. Simin Davoudi. Jennifer L. Lawrence. Eds. 2019. The Resilience Machine. New York: Routledge.

Butler, Judith. Athena Athanasiou. 2013. Dispossession: The Performance in the Political. Cambridge: Polity.

Chandler, David. Julian Reid. 2016. The Neoliberal Subject: Resilience, Adaptation and Vulnerability. London: Rowman and Littlefield.

Cosens, Barbara A. 2013. "Legitimacy, Adaptation, and Resilience in Ecosystem Management". Ecology \& Society 18(1): 3.

Craig, Anthony Arnold. Lance Gunderson. 2013. "Adaptive Law and Resilience”. Environmental Law Reporter 43: 10426-10443.

Deleuze, Gilles. 1989. Cinema 2: The Time-Image. London: Athlone.

Douzinas, Costas. Adam Gearey. 2005. Critical Jurisprudence: The Political Philosophy of Justice. Oxford and Portlan, OR: Hart Publishing.

Evans, Brad. Julian Reid. 2014. Resilient Life: The Art of Living Dangerously. Oxford: Polity.

Felli, Romain. 2016. "The World Bank's Neoliberal Language of Resilience”. In Risking Capitalism. 267-295. Edited by Susanne Soederburg. Bingley: Emerald.

Fisher, Pamela. Lisa Buckner. 2018. "Time for 'Resilience': Community Mediators Working with Marginalised Young People Offer a Novel Approach”. International Journal of Sociology and Social Policy 38(9/10): 794-808.

Folke, Carl. Steve Carpenter. Thomas Elmqvist. Lance Gunderson. C. S. Holling. Brian Walker. 2002. "Resilience and Sustainable Development: Building Adaptive Capacity in a World of Transformations". Ambio 31(5): 437-340.

Ginn, Franklin. 2015. "When Horses Won't Eat: Apocalypse and the Anthropocene". The Annals of the Association of American Geographers 105(2): 351-359.

Gorfinkel, Elena. 2012. "Weariness, Waiting: Enduration and Art Cinema's Tired Bodies". Discourse 34(2-3): 311-347.

Grear, Anna. 2015. 'Deconstructing Anthropos: A Critical Legal Reflection on 'Anthropocentric' Law and Anthropocene 'Humanity"'. Law and Critique 26(3): 225-249.

Hallegatte, Stephane. Adrien Vogt-Schilb. Mook Bangalore. Julie Rozenberg. 2017. Unbreakable: Building the Resilience of the Poor in the Face of Natural Disasters. Washington, DC: World Bank.

Hardt, Michael. Antonio Negri. 2009. Commonwealth. Cambridge, MA: Harvard University Press. I, Daniel Blake. 2016. Directed by Ken Loach. United Kingdom: Sixteen Films.

In the Air. 2009. Directed by Liza Johnson.

Kaun, Anne. Maria Francesca Murru. 2018. "Narrative Mediation of the Occupy Movement: A Case Study of Stockholm and Latvia”. In Media and Austerity: Comparative Perspectives. 226-236. Edited by Laura Basu, Steve Schifferes, Sophie Knowles. London: Routledge.

Kiraly, Hajnal. 2015. "Leave to Live? Placeless People in Contemporary Hungarian and Romanian Films of Return". Studies in Eastern European Cinema 6(2): 169-183.

Lawrenson, Edward. 2011. "Edge of Darkness: The Turin Horse”. Film Quarterly 64(4): 66-67.

Lendvay, Marton. 2016. "Resilience in Post-socialist Context: The Case of a Watermelon Producing Community in Hungary". Hungarian Geographical Bulletin 65(3): 255-269. 
Mańko, Rafał. 2018. "Critique of the 'Juridical': Some Metatheoretical Remarks". Journal of the University of Latvia. Law 11: 24-37.

Mańko, Rafał. Cosmin Cercel. Adam Sulikowski. 2016. Law and Critique in Central Europe. Oxford: Counterpress.

Menchaca, William. 2018. "Analyzing Poverty Disparities Between Eastern and Western Europe". Borgen Magazine. http://www.borgenmagazine.com/poverty-disparities-between-easternand-western-europe/

Morell, Ildikó Asztalos. Margaret Greenfields. David M. Smith. 2018. "Governing Underprivileged Roma Migrations within the EU: Receiving Country Responses and Roma Resilience". Local Economy 33(2): 123-126.

Pingali, Prabhu. Luca Alinovi. Jacky Sutton. 2005. „Food Security in Complex Emergencies: Enhancing Food System Resilience". Disasters 29(51): 5-24.

Rancière, Jacques. 2011. Bela Tarr, The Time After. Minneapolis: Univocal.

Rear Window. 1954. Directed by Alfred Hitchcock. United States: Patron Inc.

Reid, Julian. 2012. "The Disastrous and Politically Debased Subject of Resilience". Development Dialogue 58: 67-79.

Reid, Julian. 2013. "Interrogating the Sustainable Development-Resilience Nexus Biopolitically". International Political Sociology 7: 353-368.

Roberts, Phillip. 2017. "Control and Cinema: Intolerable Poverty and the Films of Bela Tarr". Deleuze Studies 11(1): 68-94.

Ruhl, J.B. 2012. "Panarchy and the Law". Ecology \& Society 17(3): 31.

Rust, Stephen. Salma Monani. 2013. "Introduction: Cuts to Dissolves - Defining and Situating Ecocinema Studies" in Ecocinema Theory and Practice. 1-13. Edited by Stephen Rust, Salma Monani, Sean Cubitt. London: Routledge

Smith, Adrian. Judit Timar. 2010. "Uneven Transformations: Space, Economy and Society 20 Years after the Collapse of State Socialism". European Urban and Regional Studies 17(2): 115-125.

Tandon, Nidhi. 2007. "Biopolitics, Climate Change and Water Security: Impact, Vulnerability and Adaptation Issues for Women". Agenda 73: 4-20.

Trawick, Paul. 2003. "Against the Privatization of Water: An Indigenous Model for Improving Existing Laws and Successfully Governing the Commons". World Development 31(6): 977996.

The Turin Horse (A Torinói Ló). 2011. Directed by Béla Tarr. Hungary: TT Filmmûhely.

UNDP [United Nations Development Programme]. 2018. Roma Data. http://www.eurasia.undp. org/content/rbec/en/home/ourwork/sustainable-development/development-planning-andinclusive-sustainable-growth/roma-in-central-and-southeast-europe/roma-data.html

UNEP [United Nations Environment Programme]. 2004. Exploring the Links: Human Well-Being, Poverty \& Ecosystem Services. Nairobi: UN Publications.

Yew-Foong, Hui. 2017. "The Umbrella Movement: Ethnographic Explorations of Communal ReSpatialization”. International Journal of Cultural Studies 20(2): 146-161. 